\title{
THE NATURE OF GENE ACTION AND THE PERFORMANCES OF HYBRIDS WITH RESPECT TO EARLINESS AND YIELD TRAITS UNDER NORMAL AND LATE SOWING DATES IN WHEAT (Triticum aestivum, L.). El - Adl, A. M. ${ }^{\star}$; Magda E. Abd El-Rahman ${ }^{\star \star}$ and M. M. Yasin ${ }^{\star \star}$ \\ * Dept. of Genetics, Fac. of Agric. , Mansoura Univ. , Egypt. \\ ** Wheat Research Dept. ; Field Crops Res. Ins., Agric. Res. Center, Egypt.
}

\begin{abstract}
This investigation was made to evaluate three bread wheat hybrids and their six populations generated from each of them under normal and late sowing dates. The three hybrids were obtained where hybrid 1 was a result of crossing (Late $\times$ Late) cultivars; hybrid 2 was a result of crossing (Early $\times$ Early) cultivars and hybrid 3 was a result of crossing (Late $\times$ Early) ones. The early parental in breed lines included:

Line1, Line2 and Line3 while, the late parental ones included: Misr2 and Gemmeiza9. The two sowing dates were: normal sowing on 29 November 2011 and the late sowing on 29 December 2011. Therefore, the total genetic materials were obtained from the three hybrids included 18 genotypes which were evaluated at Sakha Agricultural Research Station Farm, Wheat Section, Egypt.

Earliness traits showed that late sowing date required fewer days than normal sowing date for days to heading; days to maturity and grain filling period. This trend was present for all populations of the three hybrids. It appeared that late sowing shorten the life span of plants. Yield component characters which included: plant height; 100kernel weight and grain yield/ plant showed the advantage of hybrid 1 for plant height and grain yield/plant than the other two hybrids. These two characters showed a modest amounts of heterosis for the three hybrids.

Nature of gene action which estimated from the six populations and evaluated using the scaling test analysis proposed by Mather and Jinks (1971). The results indicated the importance of additive genetic variance than dominance genetic variance one for most studied traits. These results were also supported by the results obtained from the scaling test analysis as the quantities $A, B$ and $C$ indicated the adequacy of the additive dominance model.
\end{abstract}

Keywords: Heterosis; Wheat; Scaling Test and Earliness.

\section{INTRODUCTION}

Wheat(Triticum aestivum L.) is considered the most important serial crop not only in Egypt but also all over countries of the world. Therefore, plant breeders continue to execute breeding programs to improve the economical traits of wheat. For this purpose, there are two approaches which including either the production of wheat hybrids or selecting high yielding varieties. The most important desired and characters of wheat are: earliness and yield specially plant height for straw and grain yield for making bread.

Earliness traits were studied by many authors using several hybrids were obtained from different parental varieties. El-Hag (2006) studied three hybrids with respect to number of days to heading and to maturity. The results revealed that these hybrids were variable for the two studied traits. At the same time, all the six populations of each hybrid were also variable in 
their performances. Menshawy (2007) studied 15 different wheat genotypes under normal and late sowing dates. The results showed that the late sowing date reduced number of days for all earliness studied traits. The same result was obtained by Munir et. al., (2007) who reported the presence of significant differences among the six populations for days to heading and to maturity. The same trend was found by Abd El-Rahman (2008) who indicated that the six populations of each hybrid varied for days to heading; days to maturity and grain filling period. Those authors reported that all traits were affected by additive; dominance or epistasis genetic variances.

According to the scaling test analysis proposed by Mather and Jinks (1971) the results suggested the importance of additive and dominance genetic variances. However, some traits were controlled by epistatic effects. With respect to yield and its component characters Abd-el-Nour and Moshref (2006) obtained negative heterosis effects for yield component characters indicating the absence of heterosis. On the other hand, Abd-el-Nour (2006) found significant positive heterosis for plant height and grain yield/plant for some hybrids. Similarly, Moshref (2006) also obtained significant positive heterosis for yield characters. Ahmadi et al., (2007) using scaling test analysis and the results indicated the importance and significance of additive, and dominance genetic variances. The additive variance appeared to be the most important component. In general, the result indicated the adequacy of additive, dominance model.

In general, most of authors obtained variable estimates of heritability in narrow and broad senses although their values were close to each others because of the smaller values obtained for the dominance. In this respect, Aboshosha and Hammad (2009) indicated that the calculated quantities A, B and $\mathrm{C}$ of the scaling test revealed the importance of additive effect which was larger and greater than dominance effect for 100-kernel weight; grain yield/plant and plant height. Therefore, the objective of this study was directed to investigate the effect of normal and late sowing dates, on the performances of three hybrids resulted from crossing different cultivars and lines with respect to their earliness characteristics.

\section{MATERIALS AND METHODS}

In this study, five lines and cultivars were used to produce three different hybrids. The first hybrid was produced by crossing the late cultivars (Misr2) by the late one (Gemmeiza9), the second hybrid was produced by crossing the early line (Line1) by the early line (Line2), while the third one was produce by crossing the late cultivar (Gemmeiza9) and the early line (Line3).

From each hybrid, six populations were obtained which included: the two parents $\mathrm{P}_{1} ; \mathrm{P}_{2}$; the $\mathrm{F} 1$ hybrid; the $\mathrm{F}_{2}$ generation and finally the two back crosses for the two parents $\mathrm{BC}_{1}$ and for the second $\mathrm{BC}_{2}$. These six populations were planted in two sowing dates. The normal sowing date on 29 of November and the late sowing date on 29 December. Thus, the differences between the two sowing dates was 30 days. 
All populations of the three hybrids combinations were evaluated in a Randomized Complete Blocks Design (RCBD) with three replications, where each block contained the 18 genotypes. The Date were collected for the following earliness traits; days to heading; days to maturity and grain filling period. The studied yield and yield component characters included: plant height, 100- kernel weight and grain yield per plant.

The means and the variances of each genotypes were obtained at both sowing dates of the three hybrids. In addition, the analysis of variance for each hybrid was made to test the significance of the differences among the six populations of each hybrid and to obtained the estimates of heterosis and the inbreeding depression (ID\%). Heterosis was estimated for each hybrid at both sowing dates from the mid-parent $\left(\mathrm{H}_{\mathrm{MP} \%}\right)$ and from the better parent $\left(\mathrm{H}_{\mathrm{BP} \%}\right)$. Inbreeding depression (ID\%) was also obtained for each hybrid.

The six populations of each hybrid were set up in a scaling test analysis according to Mather and Jinks (1971) to test for the adequacy of additive - dominance model. Scaling test make it possible to obtain estimates for epistatic effects in addition to additive and dominance effects.

Scaling test:

Mather and Jinks (1971) suggested three quantities A, B, and C. The values of $A, B$ and $C$ should be equal to zero within the limit of their standard error. The significance of any one of these scales is taken to indicate the presence of non-allelic interaction.

Heterosis:

Heterosis was expressed as the deviation of the $F_{1}$ generation from the means of the mid-parent or the better parent values, as follows:

Heterosis over mid-parent $\left(\mathrm{H}_{\mathrm{MP} \%}\right)=\left(\overline{\mathrm{F}_{1}}-\overline{\mathrm{MP}}\right) / \mathrm{MP} \times \overline{10} 0$

Heterosis over the better-parent $\left(\mathrm{H}_{\mathrm{BP} \%}\right)=\left(\overline{\mathrm{F}_{1}}-\overline{\mathrm{BP}}\right) / \overline{\mathrm{BP}} \times 100$

To test the significance of the above estimates of heterosis, the differences were tested against the L.S.D. values at $0 . \overline{05}$ and 0.01 levels of significance as follows :

L.S.D. $0.05=\mathrm{t}($ error d.f., 0.05$) \times \mathrm{Sd}$

L.S.D. $0.01=\mathrm{t}($ error d.f., 0.01$) \times \mathrm{Sd}$

and

$\mathrm{Sd}=\sqrt{2 \mathrm{EMS} / \mathrm{r}}$ for $\mathrm{F}_{1}$ us BP

$S d=\sqrt{3 E M S / 2 r}$ for $F_{1}$ us MP

Inbreeding depression (I. D \%): equation:

Inbreeding depression could be estimated from the following

(I.D. \%) $=\left(\bar{F}_{1}-\bar{F}_{2} / \bar{F}_{1}\right) \times 100$

To test the significance of inbreeding depression, the differences between the $F_{1}$ and $F_{2}$ was obtained and tested against the L.S.D. values.

Heritability:

Heritability was computed in both broad $\left(\mathrm{h}^{2}{ }_{\mathrm{b} . \mathrm{s} \%}\right)$ and narrow $\left(\mathrm{h}^{2}{ }_{\mathrm{n} . \mathrm{s} \%}\right)$ senses from the following quantities: 
EI-Adl, A. M. et al.

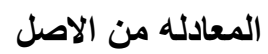

Expected gain from selection $(\Delta \mathrm{g})$ :

It was computed according to Johnson et al. (1955) as follows:

$(\Delta \mathrm{g})=\mathrm{K} \times\left(\sigma^{2} \mathrm{~F}_{2}\right)^{1 / 2} \times \mathrm{h}^{2}{ }_{\mathrm{n}}$, where:

$\mathrm{K}=\mathrm{a}$ selection differential with a value of 2.06 under $5 \%$ selection intensity.

\section{RESULTS AND DISCUSSION}

\section{HETEROSIS AND THE PERFORMANCES OF THE PARENTS AND THEIR HYBRIDS}

The means of the two parents, their $F_{1}$ hybrid and $F_{2}$ generation were obtained for the three different hybrids at both sowing dates for all studied traits and the results are presented in Table 1. The estimated amounts of heterosis from the mid $\left(\mathrm{H}_{\mathrm{MP} \%}\right)$ and the better parents $\left(\mathrm{H}_{\mathrm{BP} \%}\right)$ in addition to the inbreeding depression. The means for hybrid 1 (Late $\times$ Late) showed that the $F_{1}$ hybrid was not earlier than its two parents for: days to heading; days to maturity and grain filling period. Therefore, no heterosis would be expected for earliness traits and accordingly no I.D.\% would be obtained. On the other hand, yield characters which included: plant height, kernel weight and grain yield per plant showed superiority of the $F_{1}$ hybrid than its two parents for these traits. Therefore, heterosis from the mid and the better parents would be obtained although the estimated amounts of heterosis were modest. Inbreeding depression I.D.\% was also present for these traits but with smaller amounts.

The results indicated that the late parents also produced late hybrid and late $F_{2}$ generation. The same trend was noticed in both normal and late sowing dates. However, all earliness traits were earlier at late sowing than at the normal sowing date. In other words, all genotypes required fewer number of days at late sowing than at normal sowing. 
J.Agric.Chem.and Biotechn., Mansoura Univ.Vol. 4 (7), July, 2013

1

291 
For yield traits it was the opposite where normal sowing gave taller plants, heavier 100-kernel weight and larger grain yield per plant. Therefore, late sowing was not desired for yield traits.

For hybrid 2 (Early $\times$ Early) the two parents were early however their F1 hybrid was not earlier than the earliest parent for earliness traits. Therefore, there was no heterosis estimates were obtained for these traits. Also, the late sowing date appeared to be earlier than normal sowing date. Yield and yield component traits showed significant heterosis for: plant height, kernel weight and grain yield per plant. Once more, the normal sowing date showed better performance than late sowing date for all yield traits. Inbreeding depression for yield traits was present and significant as a result of the presence of heterosis.

For hybrid 3 (Late $\times$ Early) the same trend was observed where earliness traits were earlier at late sowing than normal sowing date. On the other hand, yield traits were better at normal sowing date than at late sowing date. An important observation was noticed where (Late $\times$ Late) hybrid gave taller plants, more grain yield and heavier 100-kernel weight than the other two hybrids.

In general, the two late parents Misr2 and Gemmeiza9 required 106 and 109days for days to heading at normal sowing, while the $F_{1}$ hybrid and $F_{2}$ generation required 108days for both of them for the same trait. For late sowing date, number of days to heading were 98.4 and 101 days for the two parents, while the $F_{1}$ and the $F_{2}$ required 100 and 101 days, respectively.

The same trend was noticed for days to heading where number of days were more for normal than late sowing for all populations. Therefore, it would be very important to determined the differences for all the three hybrids and their six populations. The differences between normal and late sowing dates for all studied traits were obtained and the results are presented in Table 2. It should be indicated this table that for earliness traits the positive differences were undesirable and the negative differences were desirable while, it is the opposite for yield traits.

The parents of the three hybrids required more days for earliness traits at normal sowing than the late sowing for days to heading. The number of days at normal sowing varied from 2.5 to 7.7 days. While, for days to maturity it ranged from 20.4 to 12.1 days. Grain filling period also showed differences in favor of late sowing date by differences ranged from 9.57 to 11.5 days. These differences were noticed for all earliness traits which indicated that late sowing date required fewer days than normal sowing date. This trend was noticed for all populations as appeared the generations in Table 2.

For yield and yield component traits the positive differences were in favor of normal sowing date. Plant height at normal sowing for $\mathrm{P}_{1}$ of the three hybrids showed differences ranged from $20.7 ; 21.7$ and $29 \mathrm{~cm}$. All these values were in favor of normal sowing date. Most populations for yield traits showed the advantage for normal sowing dates specially for plant height and grain yield/ plant.

The three hybrids were produced from different parents with respect to earliness. Therefore, it would be very interesting to compare their 
performances at normal and late sowing dates for earliness and yield traits as presented in Table 3. Hybrid 1 (Late $\times$ Late) when compared with hybrid 2 (Early $\times$ Early) showed that at required more days for days to heading of 14.6 and 12 days for normal and late sowing dates, respectively. For days to maturity number of days were 14.6 days and 10 days for normal and late sowing dates, respectively. This result indicated that when the two parents are late, they produce late $F_{1}$ hybrid. The same trend was noticed when hybrid 1 was compared with hybrid 3 but with less effect. Days to heading showed differences of 7.1and 7.37 days for normal and late sowing dates, while days to maturity showed 3.4 and 3.86 days respectively. Therefore, the differences was not large as the difference noticed when the hybrid 1 was compared with hybrid 2 . When hybrid 2 was compared with hybrid 3 it showed negative values indicated that hybrid 3 required fewer number of days than hybrid 3 for days to heading; days to maturity and grain filling period as indicated in the same Table. Similar trend was noticed for the $F_{2}$ generations of the hybrid for all earliness traits.

Table 2 : The differences of comparisons between normal $(\mathrm{N})$ versus late (L) sowing dates for all six populations for the three hybrids for all studied traits.

\begin{tabular}{|c|c|c|c|c|c|c|c|}
\hline Hybrids & $\begin{array}{c}\text { Traits } \\
\text { populations }\end{array}$ & \begin{tabular}{|} 
Days to \\
heading
\end{tabular} & $\begin{array}{l}\text { Days to } \\
\text { maturity }\end{array}$ & $\begin{array}{l}\text { Grain } \\
\text { failing } \\
\text { period }\end{array}$ & $\begin{array}{c}\text { Plant } \\
\text { height }(\mathrm{cm} .)\end{array}$ & $\begin{array}{c}100 \text { - kernel } \\
\text { weight(g) }\end{array}$ & $\begin{array}{c}\text { Grain } \\
\text { yield/plant(g) }\end{array}$ \\
\hline \multirow{6}{*}{$\begin{array}{c}\text { Hybrid } 1 \\
\text { (L×L) }\end{array}$} & $P_{1}$ & 7.70 & 19.2 & 10.4 & 20.7 & 0.610 & -1.98 \\
\hline & $\mathbf{P}_{2}$ & 7.63 & 20.4 & 11.5 & 29.3 & 1.16 & 9.44 \\
\hline & $F_{1}$ & 8.36 & 19.1 & 10.9 & 26.5 & 0.340 & 8.05 \\
\hline & $F_{2}$ & 7.33 & 16.8 & 9.66 & 25.9 & 0.850 & -0.800 \\
\hline & $\mathrm{BC}_{1}$ & 9.07 & 21.6 & 12.7 & 23.6 & 0.400 & 6.96 \\
\hline & $\mathrm{BC}_{2}$ & 6.52 & 18.8 & 12.1 & 24.3 & 1.04 & 16.1 \\
\hline \multirow{6}{*}{$\begin{array}{c}\text { Hybrid } 2 \\
\text { (ExE) }\end{array}$} & $\mathbf{P}_{1}$ & 2.50 & 12.1 & 9.57 & 21.7 & 1.46 & -0.430 \\
\hline & $\mathbf{P}_{2}$ & 0.270 & 13.4 & 13.3 & 18.3 & 1.84 & 0.660 \\
\hline & $F_{1}$ & 5.40 & 14.5 & 9.13 & 14.3 & 0.420 & 13.3 \\
\hline & $F_{2}$ & 1.28 & 15.5 & 14.2 & 12.7 & 1.24 & -3.41 \\
\hline & $\mathrm{BC}_{1}$ & -0.430 & 15.7 & 16.1 & 12.4 & 1.06 & 10.2 \\
\hline & $\mathrm{BC}_{2}$ & 1.13 & 14.7 & 13.2 & 16.5 & 1.21 & -0.850 \\
\hline \multirow{6}{*}{$\begin{array}{c}\text { Hybrid } 3 \\
\text { (L×E) }\end{array}$} & $\mathbf{P}_{1}$ & 7.63 & 20.4 & 11.5 & 29.3 & 1.16 & 9.44 \\
\hline & $\mathbf{P}_{2}$ & -0.560 & 8.50 & 8.70 & 21.0 & 0.750 & -7.34 \\
\hline & $F_{1}$ & \begin{tabular}{|l|}
8.63 \\
\end{tabular} & 19.6 & 9.60 & 30.3 & 0.870 & -3.80 \\
\hline & $F_{2}$ & 2.33 & 14.1 & 11.8 & 25.2 & 1.13 & -2.90 \\
\hline & $\mathrm{BC}_{1}$ & 4.07 & 16.8 & 12.7 & 27.3 & 1.85 & 6.20 \\
\hline & $\mathrm{BC}_{2}$ & 0.360 & 13.3 & 12.8 & 24.9 & 1.44 & -6.85 \\
\hline
\end{tabular}

Hybrid 1= Misr2 $\times$ Gemmeiza9
Hybrid 2 = Line1 $x$ Line2
Hybrid $3=$ Gemmeiza9 $\times$ Line3 
Yield and yield component traits showed that hybrid 1 exceeded hybrid 2 and hybrid 3 for plant height by 15.3 and $6.17 \mathrm{~cm}$., respectively. This result indicated that hybrid 1 (Late $\times$ Late) gave taller plants because its life span was longer than the other two hybrids. The similar trend was noticed for normal and late sowing dates. The $F_{2}$ generation also showed the advantage of the F2 of hybrid 1 than the $F_{2}$ of hybrid 2 and hybrid 3 .

In general, the results indicated that the hybrids produced from crossing (Late $\times$ Late) parents produced taller plants and yield more grains than the other hybrids although they were late for earliness traits whatever they were planted at normal or late dates. These results was in full agreement with those obtained by El-Beially and El-Sayed (2002) and Hamada (2003), who obtained significant negative heterosis effects for mid and better parents for earliness traits. These results were also in agreement with Aglan (2003), Hendawy (2003) and El-Sayed and El-Shaarawy (2006), who reported that inbreeding depression estimates were significant and negative for earliness traits. Similar conclusion were reported by Hamada (2003b) for most agronomic traits ; Hendawy (2003) for plant height and No. spikes/plant; Salem and Abd El-Dayem (2006) for 100-kernel weight; AbdEINour (2006b) for No. kernels/spike and El-Sayed and El-Shaarawy (2006) for grain yield/plant. For yield component characters, several outers are in harmony with their results among them. Abo Elala (2006), AbdEl-Nour (2006b), El-Sayed and El-Shaarawy (2006) and Mosherf (2006), who reported the presence of significant heterosis and inbreeding depression for all yield traits.

\section{NATURE OF GENE ACTION AND VARIANCE COMPONENTS FOR} EARLINESS AND YIELD CHARACTERS AT BOTH SOWING DATES

An advantage of the six populations would be manifested and applied for the estimation of the different genetic variances. The $F_{2}$ generations and the two back crosses make it possible to obtain the estimates for additive $\sigma^{2}{ }_{A}$ and dominance $\sigma^{2}$ genetic variances. At the same time, these variances would be utilized to obtain estimates for heretabilities in broad and narrow senses. In addition to obtain estimates for the expected gain from selection.

These parameters were estimated from the six populations of the three hybrids and the results are presented for normal and late sowing dates in Table 4. Additive genetic variance appeared to be larger in magnitude than the dominance genetic variance for most studied traits of earliness and for all yield components traits. This result was true for all three hybrids. It should be indicated that the magnitudes of additive and dominance genetic variance varied in normal and late sowing dates for earliness traits, where larger values were obtain for normal sowing than late sowing dates for some traits. On the other hand, it was vice versa for yield traits where the presence of significant magnitudes of dominance variance indicated its importance in the inheritance of most traits and appeared in the large estimates obtained for heterosis in broad sense. 
J.Agric.Chem.and Biotechn., Mansoura Univ.Vol. 4 (7), July, 2013

3 
EI-Adl, A. M. et al.

4 
Estimates of heritability showed that broad sense heritability exceeded their corresponding estimates of narrow sense heritability for all traits. Some

traits which showed smaller estimates for dominance variance showed a closed estimates for both types of heretabilities. It was noticed that the magnitude of the estimates of both types of heretabilities at normal sowing date were larger than their corresponding estimates of late sowing date for most traits especially for yield component traits.

Hybrid 1 showed estimates of heritability in broad sense ranged from $95.74 \%$ for days to heading at normal sowing date to $83.86 \%$ for grain filling period. While, at late sowing date, it ranged from $99.2 \%$ for grain yield/plant to $77.54 \%$ for days to maturity. Narrow sense heritability at normal sowing date ranged from $96.8 \%$ for plant height to $10.36 \%$ for days to maturity.

Expected gain from selection was either modest or small for most traits, although plant height and grain yield/plant gave large values at both normal and late sowing date indicating the possibility of improving these two traits in future breeding programs.

Hybrid 2 followed the same trend of hybrid 1 more or less but the magnitudes of additive genetic variance were larger for all traits than that of hybrid 1. The magnitude of additive variance at normal sowing date was always larger than its corresponding magnitudes at late sowing date. The magnitude of dominance genetic variance showed the same trend but not for all traits.

The magnitudes of heritability in broad sense at normal sowing were larger than corresponding estimates of heritability for late sowing date. In general, broad sense heritability ranged from $98.3 \%$ for grain yield/ plant to $40.7 \%$ for 100 - kernel weight at normal sowing date. It should be indicated that many traits gave large estimates over $90 \%$ for most traits for broad sense heretability. The estimates of narrow sense heretability ranged from $83 \%$ for plant height to $13 \%$ for 100 -kernel weight at normal sowing.

The expected gain from selection were of considerable amounts for three traits especially for plant height $(25.96 \%)$ grain yield/ plant $(45.17 \%)$ at normal sowing date. While at late sowing date the values were $(25.47 \%)$ for plant height and (54.87)\% for grain yield/ plant. Therefore, in view of this result both plant height and grain yield/ plant are the two promising traits it utilized in breeding programs.

Hybrid 3 showed intermediate values between hybrid 1 and hybrid 2 and followed similar trend. This hybrid also showed the large amounts of the expected gain from selection for plant height and grain yield/ plant at both normal and late sowing dates. Similar results were obtained by Chandra et al. (2004) ; Sharon et al. (2005) ; Hammad and Abd El-Aty (2007) ; Abd ElRahman (2008) and Hammad et. al. (2012), who reported that heritability estimates for earliness traits were moderate to high under normal sowing date. These results were also in agreement with Hamada (2003a) ; Chandhra et al. (2004) and Sharon et al. (2005). On the other hand, Hendawy (2003), found low expected genetic advance from selection for days to heading and days to maturity. Similar results were also obtained by Chowdhary and Kashif (2003) ; Hendawy (2003) ; AbdEI-Nour (2006b) and Ismail et al. (2006) who 
indicated that for most traits with respect to broad and narrow senses heritabilities varied from moderate to high at normal sowing date. While, Hamada (2003-b) found the same result under different sowing dates for most traits.

\section{NATURE OF GENE ACTION ACCORDING TO MATHER AND JINKS} (1971) SCALING TEST

he scaling test analysis proposed by Mather and Jinks (1971) assumed a genetic model suggesting that the traits are only controlled by additive and dominance genetic variances. The scaling test depends on calculated the quantities $A, B$ and $C$ along with their standard errors. If the three quantities are not significant, this would indicate that additive and dominance model would be adequate to explain the inheritance of this trait. If any one of these quantities is significant it would indicate the presence of the epistatic variances. Accordingly, the quantities $A, B$ and $C$ were calculated for all traits at both normal and late sowing dates for the three hybrids and the results are presented in Table 5.

For hybrid 1, the magnitudes of the three quantities varied and most of their values at normal and late sowing date were negative, although some estimates were positive and significant for few traits but none of them were found for yield traits. The same trend was present at normal and late sowing dates indicating the majority of studied traits agree with the adequacy of additive - dominance model with few exception for some traits.

Hybrid 2, showed similar manifestation of the three quantities with variable magnitudes with respect to significance. Some traits showed significant estimates for the three quantities $A, B$ and $C$ and some other showed negative estimates. The magnitudes of the estimates quantities varied between normal and late sowing dates with respect to their significance or being negative or positive estimates.

Hybrid 3, followed the same trend of both hybrid 1 and hybrid 2 showing variable estimates of the three quantities. Therefore, the magnitudes of the three quantities $A, B$ and $C$ indicated that additive - dominance model would be adequate for most traits, however some traits showed the presence of epistatic variances .

In order to investigate the presence or absence of epistatic effects or variances, all types of gene action were obtained according to Mather and Jinks (1971) for all traits at both sowing dates for the three hybrids and the results are presented in Table 6 . The magnitude of additive (a), dominance $(\mathrm{h})$, additive $\times$ additive (i), additive $\times$ dominance $(\mathrm{g})$ and dominance $\times$ dominance (I) along with their standard errors showed variable results for the three hybrids and at normal and late sowing for all traits. Additive variance was present and significant for some traits especially yield traits for all three hybrids. Dominance variance was also present for some traits with significant magnitude although most of the epistatic estimates for the three hybrids were either negative or insignificant. The presence of the epistatic variance for some traits was important and should be considered during breeding programs. 
J.Agric.Chem.and Biotechn., Mansoura Univ.Vol. 4 (7), July, 2013

5

299 
EI-Adl, A. M. et al.

6

300 
In general, this investigation indicated that the hybrid which produced by crossing two late varieties showed better performances especially for plant height and grain yield/ plant which exceeded the other hybrids which was produced by crossing early varieties.

The late sowing showed compensation threw the live span of wheat plant which appeared in earliness traits. Earliness traits appeared to require fewer days for days to heading, days to maturity and grain filling period than those planted at normal sowing date. The magnitude of additive and dominance model were important according to the scaling test. However, some traits showed the important of epistatic variances. Thus plant breeders must consider the effect of the epistatic variance when planning a breeding program. These results are in full agreement with those obtained by Aglan (2003) ; Hamada (2003b) ; Hammad and Abd El-Aty (2007) ; Abd El-Rahman (2008) and ShehabEldeen (2008) who reported that both additive and dominance gene effects were important in the inheritance of earliness traits under normal sowing date. These results were also in agreement with those obtained by Hendawy (2003) and Khan and Habib (2003), who indicated that additive $\times$ additive variances are important in the inheritance of earliness and yield and yield component traits for especially plant height and grain yield per plant under normal sowing date.

\section{REFERENCES}

Abdel-Nour, Nadia A. R. (2006-a). Gene effect on yield and yield components for three bread wheat crosses (Triticum aestivum L.). Egypt. J. Agric. Res., 84: 1157-1170.

Abdel-Nour, Nadia A. R. (2006-b). Genetic variation in grain yield and its components in three bread wheat crosses. Egypt. J. Plant Breed., 10: 289-304.

Abdel-Nour, Nadia A. R. and M. Kh. Mosherf (2006). Gene effect and variances in three wheat crosses using the five parameters model. Egypt. J. Plant Breed., 10: 305-318.

Abo Elala, Sabah H. (2006). Estimation of genetic parameters using five populations of some bread wheat crosses. J. Agric. Sci. Mansoura Univ., 31: 4863-4871.

Abd El-Rahman, Magada E. (2008). Genetic analysis of yield, yield components and earliness in some bread wheat crosses. Egypt. J. Agric. Res., 86: 575-584.

Aboshosha, A. A. M. and S. M. Hammad (2009). Estimation of parameters for yield and yield components and some agronomic characters in two crosses of bread wheat (Triticum aestivum, L.). J. Agric. Sci., Mansoura Univ., 34(5): 4293-4300.

Aglan, M.A.A. (2003). Breeding studies on wheat resistance to leaf and stem rusts and its association with yield and its components. M. Sc. Thesis, Fac. of Agric., Minufiya Univ., Egypt.

Ahmadi, J. ; S. F. Orang ; A. A. Zali ; B. Yazdi - Samadi ; M. R. Ghannadha and A. R. Taleei (2007). Study of yield and its components inheritance in wheat under drought and irrigated conditions. J. Sci. \& Technol. Agric. \& Natur. Resour., 11(1):214. 
Allard, A. M. (1960). Principles of Plant Breeding. Jhon Wielly and Sons. Inc. New Yourk ,U.S.A.,pp: 92.

Chandra, D. ; M. A. Islam and N. C. D. Barma (2004). Variability and interrelationship of nine quantitative characters in $\mathrm{F}_{5}$ bulk of five wheat crosses. Pakistan J. of Biol.. Sci., 7: 1040-1045.

Chowdhry, A. M. A., and M. Kashif (2003). Estimation of heritability and genetic gain of some metric traits in six hybrid populations of spring wheat. Asian J. of Plant Sci., 2: 495-497.

El-Beially, E. M. A. and E. A. M. El-Sayed (2002). Heterosis and combining ability for some bread wheat crosses. J. Agric. Sci., Mansoura Univ., 27: 5735-5744.

El-Hag, A.A. (2006). Estimation of genetic parameters for earliness and some agronomic characters in three crosses of bread wheat, (Triticum aestivum L.). J. Agric. Sci., Mansoura Univ., 31(7): 4271-4280.

El-Sayed, E.A.M. and G.A. El-Shaarawy (2006). Genetical studies on yield and some agronomic characters in some bread wheat (Triticumaestivum L.) crosses. J. Agric. Sci., Mansoura Univ., 31: 4901-4914

Hamada, A. A. (2003-a). Gene effect for some agronomic traits in three bread wheat crosses. Annals Agric. Sci. Ain Shams Univ., Cairo, 48: 131146.

Hamada, A. A. (2003-b). Heterosis and gene action of yield and its components and some growth traits in an eight parent diallel cross of bread wheat under three sowing dates. Minufiya J. Agric. Res., 28: 787-819.

Hammad, S.M., E. H. El-Seidy and M. A. H. Darwesh(2012). Inheritance of yield and its components in some spring wheat crosses. Proc. 13th international Conf. Agron.,Fac.of Agic., Benha Univ., Egypt, 206 - 221.

Hammad, S. M. and M. S. M. Abd El-Aty (2007). Diallel analysis of genetic variation for earliness and yield and its components in bread wheat. J. Agric. Res., Kaferel-Sheikh Univ., 33: 88-100.

Hendawy, H. I. (2003). Genetic architecture of yield and its components and some other agronomic traits in bread wheat. Minufiya J. Agric. Res., 28: 71-86.

Ismail, A. A., T. A. Ahmed; M.B. Tawfelis and E. M. A. Khalifa (2006). Gene action and combining ability analysis of diallel crosses in bread wheat under moisture stress and non-stress conditions. Assuit J. of Agric. Sci., 37: 17-33.

Johnson, H. W. ; H. F. Robinson and R. E. Comstock (1955). Estimation of genetic and environmental variability in soybeans. Agron. J.,47:314318.

Khan, A. and I. Habib (2003). Gene action in a five parent diallel cross of spring wheat (T. aestivum L.). Pakistan J. of Biol. Sci., 6: 1945-1948.

Mather, K. (1949). Biometrical genetics. Dover Publications, Inc., London.

Mather, K. and J. L. Jinks (1971). Biometrical Genetics $2^{\text {nd }}$ Ed. Chapman and Hall Ltd., London. 
Menshawy, A. M. M. (2007). Evaluation of some early bread wheat genotypes under different sowing dates : 1. Earliness characters. Egypt. J. Plant Breed., 11: 25-40.

Moshref, M. Kh. (2006). Studies of gene effect on yield and yield components for some bread wheat crosses. J. Agric. Sci., Mansoura Univ., 31: 3273-3283.

Munir M.; M. A. Chowdhry and M. Ahsan (2007). Generation means studies in bread wheat under drought condition, Int. J. Agri. Biol., 9(2):282-286.

Salem, Nagwa; R. A. and S. M. Abdel Dayem (2006). Genetical study on some bread wheat crosses. J. Agric. Sci. Mansoura Univ., 31: 48734883.

Sharon, J.; B.S. Tyagi; G. Singh and R.P. Singh (2005). Genetic analysis of economic traits in durum wheat. Wheat Inform. Serv., 99: 41-45.

Shehab El-deen, M. T. M. (2008). Genetic studies on earliness and drought tolerance in bread wheat. M. Sc. Thesis, Fac. of agric.Cairo, Univ., Egypt.

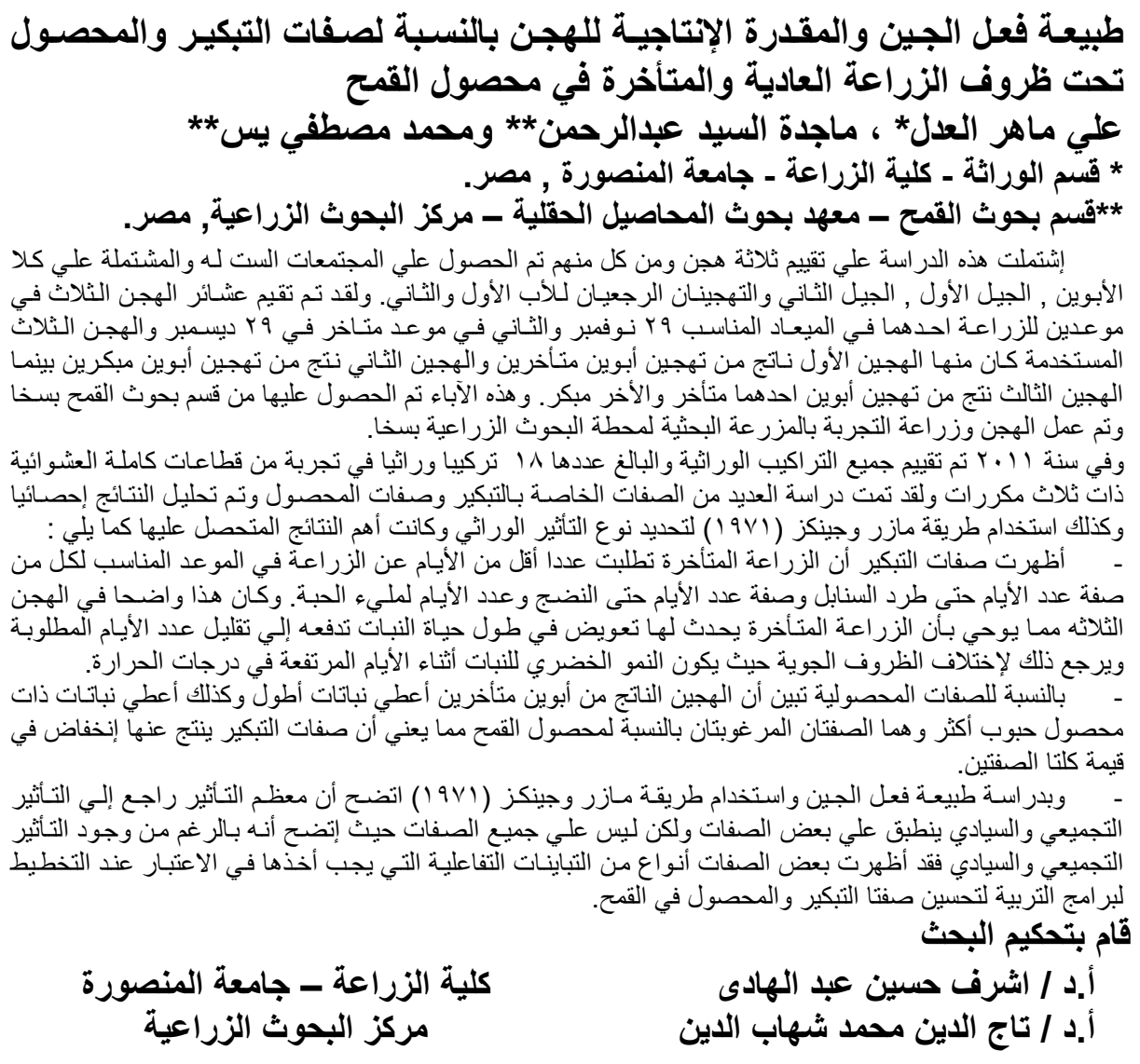


EI-Adl, A. M. et al. 